\title{
HUBUNGAN PRESTASI BELAJAR MATA PELAJARAN KEWIRAUSAHAAN DENGAN MINAT WIRAUSAHA SISWA SMK NEGERI 3 SINGARAJA
}

\author{
Ni Made Wahyuni \\ Jurusan Pendidikan Teknik Elektro, Fakultas Teknik dan Kejuruan \\ Universitas Pendidikan Ganesha \\ wahyunielektro01@gmail.com
}

\begin{abstract}
ABSTRAK
Penelitian ini bertujuan untuk mengetahui (1) prestasi belajar mata pelajaran kewirausahaan siswa SMK Negeri 3 Singaraja dan (2) hubungan antara prestasi belajar mata pelajaran kewirausahaan dengan minat wirausaha siswa SMK Negeri 3 Singaraja.

Jenis penelitian ini adalah ex-post facto yang berjenis korelasi.Populasi penelitian ini adalah seluruh siswa kelas XI dan kelas XII SMK Negeri 3 Singaraja.Jumlah populasi dalam penelitian ini adalah 1.126 orang siswa.Jumlah sampel dalam penelitian ini adalah 285 orang siswa yang dipilih dengan teknik tabel Krejcie dan Morgan dan simple randaom sampling. Data dalam penelitian ini adalah data nilai atau prestasi belajar dan data minat wirausaha siswa. Data nilai siswa dikumpulkan dengan cara mengumpulkan data skunder, yaitu mengumpulkan data yang sudah ada di sekolah dan data minat wirausaha dikumpulkan dengan angket minat wirausaha. Analisis data dilakukan dengan analisis korelasi dan regresi.

Hasil penelitian menunjukkan bahwa (1) prestasi belajar mata pelajaran kewirausahaan siswa SMK Negeri 3 Singaraja memiliki nilai siswa diatas rata-rata, yaitu 84,267 (2) terdapat hubungan yang signifikan antara nilai kewirausahaan dengan minat wirausaha $(8,180, p<0,05)$. Nilai korelasi hitung antar variabel adalah 0,152 .Hal ini menunjukkan sudah signifikan karena $r_{\text {hitung }}>r_{\text {tabel }}$. Persamaan regresi dari penelitian ini adalah $\mathrm{Y}=155,648+0,714 \mathrm{X}$.

Berdasarkan temuan dalam penelitian ini dapat disimpulkan bahwa siswa yang memiliki nilai atau prestasi belajar kewirausahaan tinggi belum tentu mempunyai minat berwirausaha tinggi.
\end{abstract}

Kata kunci: ex-post facto, prestasi belajar kewirausahaan,minat wirausaha.

ABSTRACT
This study aims to determine (1) the achievement of subjects of entrepreneurship students of SMK Negeri 3 Singaraja and (2) the relationship between achievement entrepreneurship subjects with students' entrepreneurial interest SMK Negeri 3 Singaraja. This type of research is the ex-post facto correlation manifold. The study population was all students of class XI and class XII SMK Negeri 3 Singaraja. Total population in this study was 1,126 students. The number of samples in this study were 285 students were selected by krejcie table and Morgan technique and simple randaom sampling. The data in this study are data values or learning achievement data and student interest in entrepreneurship. Data student scores are collected by collecting secondary data, which collects the data that already exists in the school and the data was collected by questionnaire entrepreneurial interests entrepreneurial interests. Data was analyzed using correlation and regression analysis.

The results showed that (1) the achievement of subjects of entrepreneurship students of SMK Negeri 3 Singaraja has a student scores above average, ie 84.267 (2) there is a significant correlation between the value of the entrepreneurial interests of entrepreneurs $(8.180, p<0.05)$. Calculate correlation values between variables is 0.152 . It showed already significant because $r_{\text {hitung }}>r_{\text {tabel }}$. The regression equation of this study is $\mathrm{Y}=155.648+0,714 \mathrm{X}$. 
Based on the findings in this study can be concluded that students who have high grades or entrepreneurial accomplishment does not necessarily have a high interest in entrepreneurship.

Keywords: ex-post facto, entrepreneurial achievement, interest in entrepreneurship.

\section{PENDAHULUAN}

Situasi perekonomian Indonesia saat ini mempunyai dampak yang sangat berkepanjangan pada dunia usaha khususnya industri.Banyak perusahaan atau industri yang tidak mampu bersaing, berproduksi dan berkembang sehingga menjadi terpuruk dan akhirnya gulung tikar.Seiring dengan pesatnya pertambahan jumlah penduduk di Indonesia dalam era globalisasi dan industrialisasi dewasa ini menimbulkan banyak permasalahan, yang salah satunya adalah menyempitnya lapangan pekerjaan. Lebih banyak orang yang mencari kerja dibandingkan kesempatan kerja yang ada, sehingga banyak orang yang tidak mendapatkan kesempatan kerja. Akibatnya jumlah pengangguran akan semakin besar yang akan berdampak pada perekonomian Indonesia. Belakangan ini banyak perusahaan-perusahaan yang mengurangi jumlah tenaga kerjanya sehingga pengangguran pun semakin bertambah. Apabila orang tersebut tidak mempunyai minat untuk menciptakan lapangan pekerjaan sendiri (berwirausaha) dan hanya mengandalkan pekerjaan dari orang lain atau bekerja pada instansi pemerintah maka pengangguran akan semakin bertambah banyak. Pengangguran di Indonesia hampir separuhnya disumbangkan oleh lulusan Sekolah Menengah Umum dan/atau Kejuruan.

Angka lulusan Sekolah Menengah Umum/Kejuruan yang setiap tahun bertambah jumlahnya tetapi tidak tahu hendak kemana karena lapangan kerja yang tersedia semakin sempit atau bahkan menjadi hilang.Pihak instansi pemerintah dan swasta sudah tidak bisa diharapkan lagi keberadaannya.Meningkatnyajumlah pengangguran akibat dari lapangan pekerjaan yang sempit membuat banyakulusan Sekolah Menengah Umum/Kejuruan yang tidak bisa melanjutkan ke Perguruan Tinggi, mengganggur karena tingkat persaingan dalam melamar pekerjaan semakin tinggi.Hal ini tentu menjadi beban masyarakatkarena jumlah pengangguran yang tinggi dapat memicu tindak kejahatan.Salah satu solusi yang ditawarkan pemerintah untuk mengurangi pengangguran adalah dengan menciptakan lapangan pekerjaan yang padat karya. Namun, kalangan terdidik cenderung menghindari pilihan pekerjaan ini karena preferensi mereka terhadap pekerjaan kantoran lebih tinggi. Preferensi yang lebih tinggi didasarkan pada perhitungan biaya yang telah mereka keluarkan selama menempuh pendidikan dan mengharapkan tingkat pengembalian (rate of return) yang sebanding. Pilihan status pekerjaan utama para lulusan Sekolah MenengahUmum/Kejuruan adalah sebagai karyawan atau buruh dalam artian bekerja pada orang lain atau instansi atau perusahaan dengan menerima upah atau gaji secara 
rutin. Kecilnya minat berwirausaha dikalangan lulusan Sekolah Menengah Umum/Kejuruan sangat disayangkan. Harusnya, melihat kenyataan bahwa lapangan kerja yang ada tidak memungkinkan untuk menyerap seluruh lulusan Sekolah Menengah Umum/Kejuruan di Indonesia, para lulusan Sekolah Menengah Umum/Kejuruan yang tidak melanjutkan ke Perguruan Tinggi agar memilih berwirausaha sebagai pilihan karirnya.

Upaya untuk mendorong hal ini mulai terlihat dilakukan oleh kalangan institusi pendidikan.Kurikulum yang telah memasukkan mata pelajaran kewirausahaan telah marak. Dengan diajarkannya mata pelajaran kewirausahaan akan semakin menambah pengetahuan siswa tentang wirausaha. Hal ini diharapkan akan semakin menumbuhkan minat berwirausaha siswa sehingga mampu menciptakan lapangan pekerjaan sendiri dengan keterampilan yang dimiliki. Namun demikian, hasilnya masih belum terlihat. Para lulusan SMU/SMK masih enggan untuk langsung terjun sebagai wirausahawan, dibuktikan dengan angka pengangguran lulusan SMU/SMK ternyata malah makin meningkat yang dapat dilihat pada tabel 1. Pada tabel tersebut dilihat bahwa jumlah pengangguran pada bulan Agustus 2011 sebesar 7.700.086 jiwa dan paling besar disumbangkan oleh pengangguran dari SMTA (Umum dan Kejuruan) 3.074.946 jiwa.

Tabel 1. Pengangguran Terbuka*) menurut pendidikan tertinggi yang ditamatkan tahun 2004, 2005, 2006, 2007, 2008, 2009, 2010, dan 2011

\begin{tabular}{|c|c|c|c|c|c|c|c|c|c|c|c|c|c|c|c|c|}
\hline $\begin{array}{l}\mathrm{N} \\
0 .\end{array}$ & $\begin{array}{l}\text { Pendidikan } \\
\text { Tertinggi Yang } \\
\text { Ditamatkan }\end{array}$ & 2004 & $\begin{array}{l}2005 \\
\text { (Feb) }\end{array}$ & $\begin{array}{l}2005 \\
\text { (Nov) }\end{array}$ & $\begin{array}{l}2006 \\
(\mathrm{Feb})\end{array}$ & $\begin{array}{l}2006 \\
\text { (Agst) }\end{array}$ & $\begin{array}{l}2007 \\
(\mathrm{Feb})\end{array}$ & $\begin{array}{l}2007 \\
(\text { Agst) }\end{array}$ & $\begin{array}{l}2008 \\
(\mathrm{Feb})\end{array}$ & $\begin{array}{l}2008 \\
(\text { Agst) }\end{array}$ & $\begin{array}{l}2009 \\
(\mathrm{Feb})\end{array}$ & $\begin{array}{l}2009 \\
\text { (Agst) }\end{array}$ & $\begin{array}{l}2010 \\
(\mathrm{Feb})\end{array}$ & $\begin{array}{l}2010 \\
\text { (Agst) }\end{array}$ & $\begin{array}{l}2011 \\
(\mathrm{Feb})\end{array}$ & $\begin{array}{l}2011 \\
(\text { Agst) }\end{array}$ \\
\hline 1 & \begin{tabular}{|l|} 
Tidak/Belum \\
Pernah \\
Sekolah/Belum \\
Tamat SD \\
\end{tabular} & $\begin{array}{l}1004 \\
296\end{array}$ & $\begin{array}{l}1012 \\
711\end{array}$ & $\begin{array}{l}937 \\
985\end{array}$ & $\begin{array}{l}849 \\
425\end{array}$ & $\begin{array}{l}781 \\
920\end{array}$ & $\begin{array}{l}666 \\
066\end{array}$ & $\begin{array}{l}532 \\
820\end{array}$ & $\begin{array}{l}528 \\
195\end{array}$ & $\begin{array}{l}547 \\
038\end{array}$ & 476302 & 637901 & 606230 & $\begin{array}{l}757 \\
807\end{array}$ & $\begin{array}{l}645 \\
081\end{array}$ & 877265 \\
\hline 2 & Sekolah Dasar & $\begin{array}{l}2275 \\
281\end{array}$ & $\begin{array}{l}2540 \\
977\end{array}$ & $\begin{array}{l}2729 \\
915\end{array}$ & $\begin{array}{l}2675 \\
459\end{array}$ & $\begin{array}{l}2589 \\
699\end{array}$ & $\begin{array}{l}2753 \\
548\end{array}$ & $\begin{array}{l}2179 \\
792\end{array}$ & $\begin{array}{l}2216 \\
748\end{array}$ & $\begin{array}{l}2099 \\
968\end{array}$ & $\begin{array}{r}214374 \\
7\end{array}$ & 1531671 & $\begin{array}{l}1522 \\
465\end{array}$ & $\begin{array}{l}1402 \\
858\end{array}$ & $\begin{array}{l}1 \\
275 \\
890 \\
\end{array}$ & 1120090 \\
\hline 3 & SLTP & $\begin{array}{l}2690 \\
912\end{array}$ & $\begin{array}{l}2680 \\
810\end{array}$ & $\begin{array}{l}3151 \\
231\end{array}$ & $\begin{array}{l}2860 \\
007\end{array}$ & $\begin{array}{l}2730 \\
045\end{array}$ & $\begin{array}{l}2643 \\
062\end{array}$ & $\begin{array}{l}2264 \\
198\end{array}$ & $\begin{array}{l}2166 \\
619\end{array}$ & $\begin{array}{l}1973 \\
986\end{array}$ & $\begin{array}{r}205468 \\
2\end{array}$ & 1770823 & $\begin{array}{l}1657 \\
452\end{array}$ & $\begin{array}{l}1661 \\
449\end{array}$ & $\begin{array}{l}1 \\
803 \\
009\end{array}$ & 1890755 \\
\hline 4 & $\begin{array}{l}\text { SMTA (Umum } \\
\text { dan Kejuruan) }\end{array}$ & $\begin{array}{l}3695 \\
504\end{array}$ & $\begin{array}{l}3911 \\
502\end{array}$ & $\begin{array}{l}5106 \\
915\end{array}$ & $\begin{array}{l}4047 \\
016\end{array}$ & $\begin{array}{l}4156 \\
708\end{array}$ & $\begin{array}{l}3745 \\
035\end{array}$ & $\begin{array}{l}4070 \\
553\end{array}$ & $\begin{array}{l}3369 \\
959\end{array}$ & $\begin{array}{l}3812 \\
522\end{array}$ & $\begin{array}{r}347121 \\
3\end{array}$ & 3879471 & $\begin{array}{l}3448 \\
137\end{array}$ & $\begin{array}{l}3344 \\
315\end{array}$ & \begin{tabular}{|l|}
3 \\
346 \\
477 \\
\end{tabular} & 3074946 \\
\hline 5 & $\begin{array}{l}\text { Diploma } \\
\text { I/II/III/Akademi }\end{array}$ & $\begin{array}{l}237 \\
251\end{array}$ & $\begin{array}{l}322 \\
836\end{array}$ & $\begin{array}{l}308 \\
522\end{array}$ & $\begin{array}{l}297 \\
185\end{array}$ & $\begin{array}{l}278 \\
074\end{array}$ & $\begin{array}{l}330 \\
316\end{array}$ & $\begin{array}{l}397 \\
191\end{array}$ & $\begin{array}{l}519 \\
867\end{array}$ & $\begin{array}{l}362 \\
683\end{array}$ & $\begin{array}{l}486 \\
399\end{array}$ & 441100 & 538186 & $\begin{array}{l}443 \\
222\end{array}$ & $\begin{array}{l}434 \\
457\end{array}$ & 244687 \\
\hline 6 & Universitas & $\begin{array}{l}348 \\
107 \\
\end{array}$ & $\begin{array}{l}385 \\
418 \\
\end{array}$ & $\begin{array}{l}395 \\
538 \\
\end{array}$ & $\begin{array}{l}375 \\
601 \\
\end{array}$ & $\begin{array}{l}395 \\
554 \\
\end{array}$ & $\begin{array}{l}409 \\
890 \\
\end{array}$ & $\begin{array}{l}566 \\
588 \\
\end{array}$ & $\begin{array}{r}626 \\
202 \\
\end{array}$ & $\begin{array}{l}598 \\
318 \\
\end{array}$ & $\begin{array}{l}626 \\
621 \\
\end{array}$ & 701651 & 820020 & $\begin{array}{l}710 \\
128 \\
\end{array}$ & $\begin{array}{l}612 \\
717 \\
\end{array}$ & 492343 \\
\hline & Total & $\begin{array}{l}10251 \\
351\end{array}$ & $\begin{array}{l}10854 \\
254\end{array}$ & $\begin{array}{l}12630 \\
106\end{array}$ & $\begin{array}{l}11104 \\
693\end{array}$ & $\begin{array}{l}10932 \\
000\end{array}$ & $\begin{array}{l}10547 \\
917\end{array}$ & $\begin{array}{l}10011 \\
142\end{array}$ & $\begin{array}{l}9427 \\
590\end{array}$ & $\begin{array}{l}9394 \\
515\end{array}$ & $\begin{array}{l}9258 \\
964\end{array}$ & 8962617 & $\begin{array}{l}8592 \\
490\end{array}$ & $\begin{array}{l}8319 \\
779\end{array}$ & \begin{tabular}{|l|}
8 \\
117 \\
631 \\
\end{tabular} & 7700086 \\
\hline
\end{tabular}


*) Mencari pekerjaan, mempersiapkan usaha, merasa tidak mungkin mendapatkan pekerjaan, sudah punya pekerjaan tetapi belum mulai bekerja

Sumber: Survei Angkatan Kerja Nasional (SAKERNAS) 2004, 2005, 2006, 2007, 2008, 2009, 2010, dan 2011

Prestasi belajar mata pelajaran kewirausahaan diharapkan akan berhubungan dengan minat berwirausaha siswa. Prestasi belajar yang didapat serta pengetahuan yang dipahami dengan baik memungkinkan tingginya minat berwirausaha, sebaliknya siswa yang prestasi belajar kewirausahaannya rendah memungkinkan rendahnya minat berwirausaha, jadi minat wirausaha itu akan timbul jika sebelumnya siswa memiliki prestasi belajar kewirausahaan yang baik. Minat berwirausaha merupakan kesediaan untuk bekerja keras dan tekun untuk mencapai kemajuan usahanya, kesediaan untuk menanggung macam-macam resiko berkaitan dengan tindakan berusaha yang dilakukannya, bersedia menempuh jalur atau cara baru, kesediaan untuk hidup hemat, kesediaan belajar dari kegagalan yang dialami.

Siswa lulusan SMK yang tidak melanjutkan ke Perguruan Tinggi diharapkan setelah lulus tidak lagi menjadi pencari kerja tetapi menjadi pencipta lapangan pekerjaan. Dengan kata lain, mereka menjadi entrepreneur dan intrapreneur. Entrepreneur, artinya setelah lulus siswa diharapkan bisa membuka lapangan pekerjaan, sedangkan intrapreneur adalah siswa diharapkan memiliki sikap-sikap wirausaha. Pengetahuan dan keterampilan siswa yang diperoleh selama bangku sekolah merupakan modal dasar yang dapat digunakan untuk berwirausaha. Pengetahuan, keterampilan, pengalaman praktek kerja lapangan serta kemampuan kerja yang dimiliki siswa dapat mendorong tumbuhnya minat berwirausaha. Minat berwirausaha akan menjadikan seseorang untuk lebih giat mencari dan memanfaatkan peluang usaha dengan mengoptimalkan potensi yang dimiliki. Dengan demikian perlu adanya penelitian yang mendalam untuk mencari tahu faktor-faktor yang dapat mendorong lulusan SMU/SMK mengambil wirausaha sebagai pilihan karirnya. Apakah mata pelajaran kewirausahaan memang efektif untuk bisa menghasilkan wirausahawan baru.

Tujuan dari penelitian ini adalah untuk mengetahui prestasi belajar kewirausahaan siswa SMK Negeri 3 Singaraja, untuk mengetahui minat wirausaha siswa SMK Negeri 3 Singaraja, dan untuk menjelaskan hubungan prestasi belajar kewirausahaan dengan minat wirausaha siswa SMK Negeri 3 Singaraja. Sedangkan manfaat yang diharapkan dari penelitian ini adalah dapat menambah khasanah hasil penelitian mengenai fakta empiris dari hubungan atau kontribusi mata pelajaran 
kewirausahaan terhadap minat wirausaha, serta diharapkan dapat menjadi literatur untuk penelitian lebih lanjut yang relevan dimasa yang akan datang.

\section{METODE PENELITIAN}

Jenis penelitian ini merupakan penelitian Ex-post Facto, yaitu penelitian yang dilakukan untuk meneliti suatu peristiwa yang sudah terjadi dan kemudian merunut kebelakang untuk mengetahui faktor-faktor yang dapat menyebabkan timbulnya kejadian tersebut. Jenis penelitian yang digunakan dalam peneltian ini adalah dengan menggunakan penelitian kualitatif dengan pendekatan kuantitatif, yang artinya penelitian menggunakan kuesioner yang kemudian diangkakan dan tergolong penelitian deskriptif korelasional dengan pendekatan kuantitatif.

Subjek penelitian ini adalah siswa kelas XI dan kelas XII SMK Negeri 3 Singaraja karena sudah menempuh mata pelajaran kewirausahaan, yaitu pada saat kelas $\mathrm{X}$ dan kelas XI. Objek penelitian, yaitu tentang minat berwirausaha siswa.

Teknik pengambilan sampel dalam penelitian ini adalah dengan teknik purposive sampling, yaitu proses pengambilan sampel yang dipilih berdasarkan pertimbanganpertimbangan tertentu, misalnya dalam penelitian ini pertimbangannya adalah siswa kelas XI dan kelas XII SMK Negeri 3 Singaraja yang sudah menempuh mata pelajaran kewirausahaan dari kelas X dan XI. Disamping itu,, tahap pengambilan sampel dilakukan dengan cara teknik random sampling untuk menentukan siswa sebagai sampel.

Dalam penelitian ini metode yang digunakan adalah metode dokumentasi dan kuesioner (angket), yaitu peneliti menggunakan pedoman (instrumen) dokumentasi berupa daftar identitas siswa serta prestasi belajar kewirausahaan siswa. Nama-nama siswa yang termasuk dalam kategori atau persyaratan dalam penelitian ini dicatat atau didokumentasikan. Dari nama-nama siswa inilah kuesioner atau angket akan diberikan.

\section{HASIL PENELITIAN DAN PEMBAHASAN}

\subsection{Hasil Penelitian}

\section{Deskripsi Umum Prestasi Belajar Kewirausahaan}

Berdasarkan data yang diperoleh untuk nilai kewirausahaan siswa diperoleh skor rata-rata $(\mathrm{M})$, dan standar deviasi (SD) sebagai berikut: 
Tabel 2. Deskripsi Nilai Kewirausahaan

\section{Statistics}

Nilai

\begin{tabular}{|c|c|}
\hline $\mathrm{N} \quad$ Valid & 285 \\
\hline Missing & 0 \\
\hline Mean & 84.2667 \\
\hline Median & 85.0000 \\
\hline Std. Deviation & 4.79426 \\
\hline Variance & 22.985 \\
\hline Range & 20.00 \\
\hline Minimum & 75.00 \\
\hline Maximum & 95.00 \\
\hline Sum & $2.40 \mathrm{E} 4$ \\
\hline
\end{tabular}

Tabel 3. Distribusi Statistik Nilai Kewirausahaan

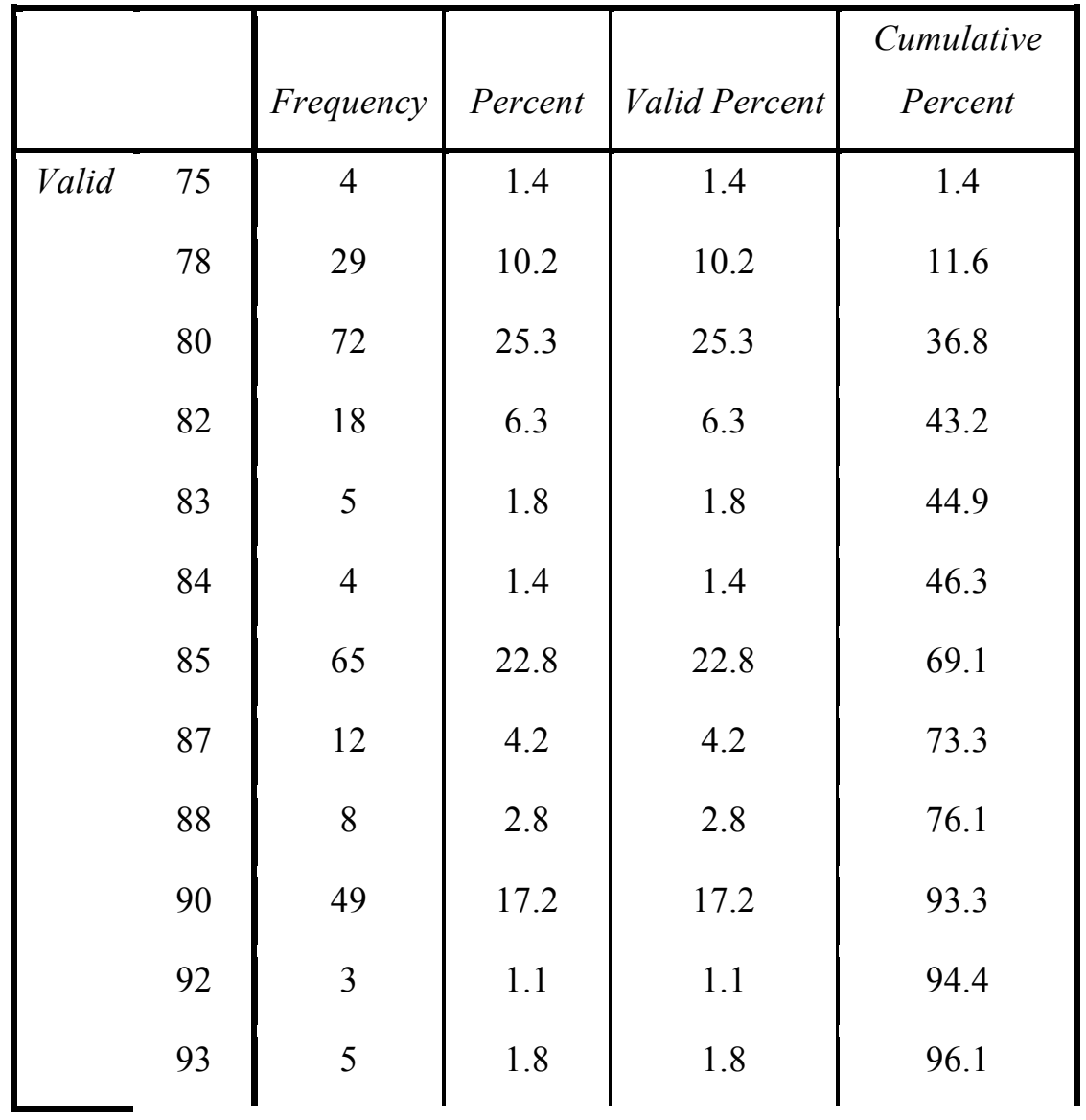




\begin{tabular}{|c|c|c|c|c|}
\hline 94 & 2 & .7 & .7 & 96.8 \\
95 & 9 & 3.2 & 3.2 & 100.0 \\
Total & 285 & 100.0 & 100.0 & \\
\hline
\end{tabular}

Dari tabel 2 diatas, dapat dijabarkan skor rata-rata (M) nilai kewirausahaan adalah 84,27, dengan skor maksimum 95, skor minimum 75 dan dengan range skor 20. Berdasarkan tabel 3 diatas, maka bisa dibuat interval kelas yang ditunjukkan pada tabel 4. Untuk distribusi frekuensi nilai kewirausahaan dapat ditentukan dengan menentukan banyaknya kelas:

$$
\begin{aligned}
& (\mathrm{k})=1+3,3 \log \mathrm{n} \text { (Rumus Sturgess) } \\
& \mathrm{k}=1+3,3 \log 285 \\
& \mathrm{k}=1+3,3 \times 2,45 \\
& \mathrm{k}=1+8,1 \\
& \mathrm{k}=9,1 \sim 9
\end{aligned}
$$

Dengan panjang kelas $=\frac{\mathrm{R}}{\mathrm{k}}=\frac{20}{9}=2,22 \sim 2$. Perhitungan kelas interval adalah sebagai berikut:
1. $75+2-1=76$
2. $77+2-1=78$
3. $79+2-1=80$
4. $81+2-1=82$
5. $83+2-1=84$
6. $85+2-1=86$
7. $87+2-1=88$
8. $89+2-1=90$
9. $91+2-1=92$
10. $93+2-1=94$
11. $95+2-1=96$

Dengan demikian dapat ditampilkan tabel frekuensi nilai kewirausahaan sebagai berikut:

Tabel 4. DistribusiFrekuensi Nilai Kewirausahaan

\begin{tabular}{|l|l|l|l|}
\hline NO & KELAS INTERVAL & FREKUENSI & PERSENTASE \\
\hline 1 & $75-76$ & 4 & $1,40 \%$ \\
\hline 2 & $77-78$ & 29 & $10,18 \%$ \\
\hline 3 & $79-80$ & 72 & $25,26 \%$ \\
\hline 4 & $81-82$ & 18 & $6,32 \%$ \\
\hline
\end{tabular}




\begin{tabular}{|l|l|l|l|}
\hline NO & KELAS INTERVAL & FREKUENSI & PERSENTASE \\
\hline 5 & $83-84$ & 9 & $3,16 \%$ \\
\hline 6 & $85-86$ & 65 & $22,81 \%$ \\
\hline 7 & $87-88$ & 20 & $7,02 \%$ \\
\hline 8 & $89-90$ & 49 & $17,19 \%$ \\
\hline 9 & $91-92$ & 3 & $1,05 \%$ \\
\hline 10 & $93-94$ & 7 & $2,46 \%$ \\
\hline 11 & $95-96$ & 9 & $3,16 \%$ \\
\hline
\end{tabular}

Berdasarkan tabel diatas maka dapat dijabarkan nilai kewirausahaan sebagian besar berada pada interval $79-80$ dan pada interval $85-86$.

\section{Deskripsi Umum Minat Wirausaha}

Deskripsi umum untuk minat wirausaha dijabarkan pada tabel 5 berikut ini:

Tabel 5. Deskripsi Minat Wirausaha

\section{Statistics}

Minat

\begin{tabular}{|c|c|c|}
\hline $\mathrm{N}$ & Valid & 285 \\
\hline & Missing & 0 \\
\hline $\mathrm{Mec}$ & & 2.1679E2 \\
\hline $\mathrm{Mec}$ & & $2.1600 \mathrm{E} 2$ \\
\hline & iation & $2.29050 \mathrm{E} 1$ \\
\hline Var & & 524.641 \\
\hline Ran & & 154.00 \\
\hline Min & & 111.00 \\
\hline$M a$ & & 265.00 \\
\hline Sun & & $6.18 \mathrm{E} 4$ \\
\hline
\end{tabular}

Berdasarkan tabel 5 diatas, dapat dilihat bahwa skor rata-rata (M) untuk minat wirausaha siswa adalah 215,85 dengan skor maksimum 265, skor minimum 111 dan range skor 154 . Karena sampelnya sama maka banyaknya kelas juga sama, yaitu 9 sehingga bisa dihitung panjang kelas $=\frac{\mathrm{R}}{\mathrm{k}}=\frac{154}{9}=17,11 \sim 17$. Perhitungan kelas intervalnya adalah sebagai berikut: 
1. $111+17-1=127$

2. $128+17-1=144$

3. $145+17-1=161$

4. $162+17-1=178$

5. $179+17-1=195$

Tabel 6. Distribusi Frekuensi Minat Wirausaha

\begin{tabular}{|l|l|l|l|}
\hline NO & KELAS INTERVAL & FREKUENSI & PERSENTASE \\
\hline 1 & $111-127$ & 1 & $0,35 \%$ \\
\hline 2 & $128-144$ & - & - \\
\hline 3 & $145-161$ & - & - \\
\hline 4 & $162-178$ & 5 & $1,75 \%$ \\
\hline 5 & $179-195$ & 279 & $97,89 \%$ \\
\hline
\end{tabular}

Untuk mendapatkan gambaran yang lebih jelas, distribusi frekuensi minat wirausaha dapat digambarkan dalam bentuk histogram berikut:

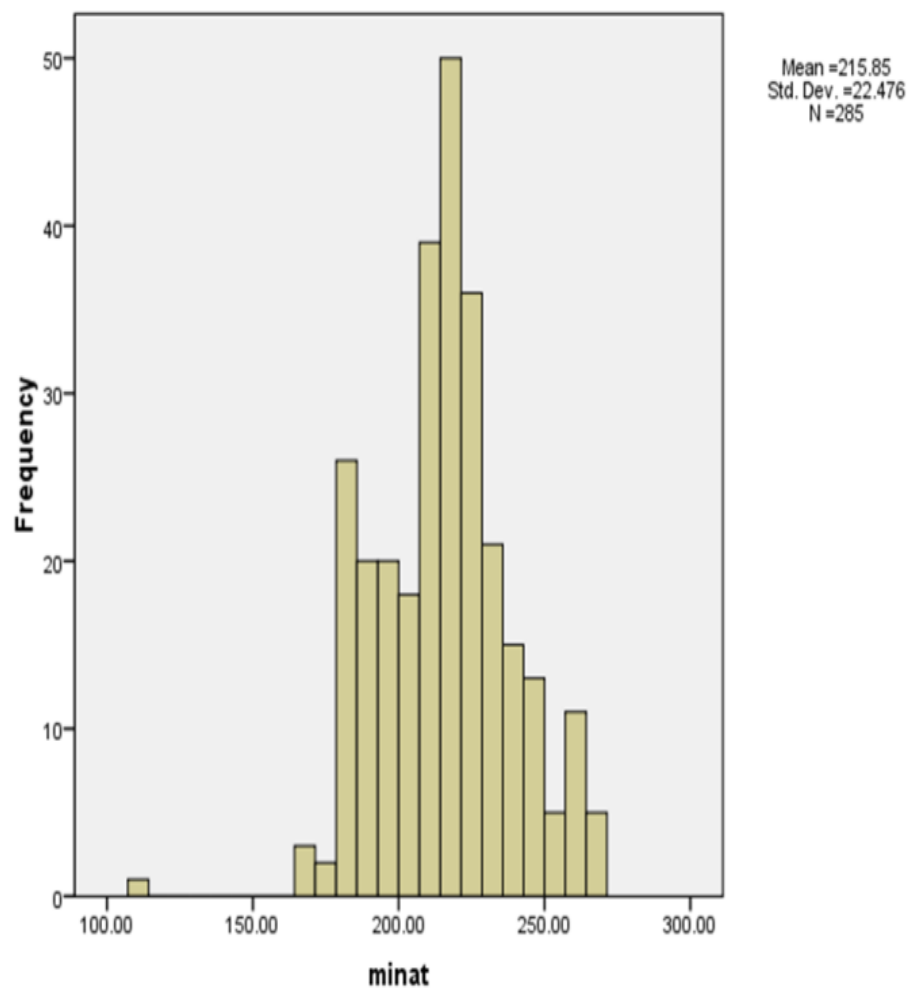

Gambar 1. Histogram skor minat wirausaha siswa 
Berdasarkan tabel 6 dan gambar 1 diatas, maka dapat dilihat bahwa minat wirausaha siswa sebagian besar terletak pada interval 179 - 195. Selanjutnya untuk menentukan kategori skor kecendrungan minat wirausaha terlebih dahulu dihitung:

$\mathrm{Mi}=1 / 2($ skor maksimum ideal + skor minimum ideal $)=1 / 2(265+53)=160$

$\mathrm{Sdi}=1 / 6($ skor maksimum ideal - skor minimum ideal $)=1 / 6(265-53)=35$

$$
\begin{array}{ll}
\mathrm{Mi}+2 \mathrm{Sdi} \leq \mathrm{X} \leq \mathrm{Mi}+3.0 \mathrm{Sdi} & \rightarrow \text { Sangat Tinggi } \\
\mathrm{Mi}+1 \mathrm{Sdi} \leq \mathrm{X} \leq \mathrm{Mi}+2 \mathrm{Sdi} & \rightarrow \text { Tinggi } \\
\mathrm{Mi}-1 \mathrm{Sdi} \leq \mathrm{X} \leq \mathrm{Mi}+1 \mathrm{Sdi} & \rightarrow \text { Sedang } \\
\mathrm{Mi}-2 \mathrm{Sdi} \leq \mathrm{X} \leq \mathrm{Mi}-1 \mathrm{Sdi} & \rightarrow \text { Rendah } \\
\mathrm{Mi}-3 \mathrm{Sdi} \leq \mathrm{X} \leq \mathrm{Mi}-2 \mathrm{Sdi} & \rightarrow \text { Sangat Rendah }
\end{array}
$$

Berdasarkan hasil perhitungan, selanjutnya disusun kategori skor minat wirausaha, seperti pada tabel 7 berikut ini:

Tabel 7. Kategori Minat Wirausaha

\begin{tabular}{|l|l|l|l|l|}
\hline NO & INTERVAL & KATEGORI & FREKUENSI & PERSENTASE \\
\hline 1 & $230 \leq \mathrm{X} \leq 265$ & Sangat Tinggi & 70 & $24,56 \%$ \\
\hline 2 & $195 \leq \mathrm{X} \leq 230$ & Tinggi & 163 & $57,19 \%$ \\
\hline 3 & $125 \leq \mathrm{X} \leq 195$ & Sedang & 52 & $18,25 \%$ \\
\hline 4 & $90 \leq \mathrm{X} \leq 125$ & Rendah & 0 & 0 \\
\hline 5 & $55 \leq \mathrm{X} \leq 90$ & Sangat Rendah & 0 & 0 \\
\hline
\end{tabular}

Berdasarkan tabel 7 dapat dilihat bahwa minat wirausaha siswa sebanyak $24,56 \%$ berada pada kategori sangat tinggi, $57,19 \%$ berada pada kategori tinggi dan $18,25 \%$ berada pada kategori sedang.

\section{Analisis Data dan Pengujian Hipotesis}

Analisis data yang dimaksud disini adalah analisis korelasi dan analisis regresi. Sebelum dilakukan uji hipotesis, terlebih dahulu dilakukan pengujian terhadap persyaratan-persyaratan yang diperlukan terhadap sebaran data hasil penelitian. Uji prasyarat analisis meliputi dua hal, yaitu uji normalitas data terhadap keseluruhan unit analisis dan uji linieritas data terhadap keseluruhan unit analisis. 


\subsection{Pembahasan}

\section{Prestasi Belajar Kewirausahaan Siswa SMK Negeri 3 Singaraja}

Dari hasil analisis dan deskripsi diatas dapat dilihat bahwa nilai atau prestasi belajar siswa untuk mata pelajaran kewirausahaan tergolong tinggi dengan rata-rata sebesar 84,267 dan simpangan baku sebesar 4,794.

\section{Minat Wirausaha Siswa SMK Negeri 3 Singaraja}

Dari hasil analisis dan deskripsi diatas dapat dilihat bahwa minat wirausaha siswa tergolong tinggi dengan rata-rata 215,85 dan simpangan baku sebesar 224,75. Data penelitian minat wirausaha ini memiliki nilai minimum sebesar 111 dan nilai maksimum sebesar 265 .

\section{Hubungan Prestasi Belajar Kewirausahaan dengan Minat Wirausaha}

Berdasarkan hasil analisis, hipotesis penelitian yang diajukan dalam penelitian ini telah diterima, yaitu terdapat hubungan yang positif antara prestasi belajar kewitausahaan dengan minat wirausaha siswa SMK Negeri 3 Singaraja, maka berikut akan dibahas lebih lanjut kemungkinan penyebab lemahnya korelasi antara prestasi belajar dengan minat wirausaha.

Dalam kegiatan pembelajaran, semua proses belajar ditujukan pada pencapaian kompetensi siswa. Kompetensi siswa dalam pendidikan meliputi sikap positif, pemahaman konsep, kemampuan pemecahan masalah dan keterampilan menggunakan pengetahuan secara bermakna. Selain itu, segala proses pendidikan ditujukan pada pencapaian output secara optimal, output siswa sering ditampilkan dalam bentuk ranah kognitif, apektif, dan psikomotor. Penelitian ini didesain untuk mencari hubungan (korelasi) antara prestasi belajar kewirausahaan (ranah kognitif) dengan minat wirausaha (apektif).

Kewirausahaan diartikan suatu sikap, jiwa yang aktif, kreatif, inovatif dan kemampuan untuk menciptakan sesuatu yang baru yang sangat bernilai dan berguna bagi dirinya dan orang lain. Sedangkan minat adalah dorongan atau motivasi yang tinggi dari seseorang yang menjadi penggerak seseorang untuk melakukan sesuatu guna mewujudkan pencapaian tujuan dan cita-cita yang menjadi keinginannya, dimana hal ini merupakan proses pengalaman belajar yang dilakukan dengan penuh kesadaran dan mendatangkan perasaan senang, suka dan gembira. Hal ini sesuai dengan regresi sederhana dalam pengujian hipotesis dengan menggunakan program SPSS-PC 16.0 for Windows diperoleh persamaan regresi $\mathrm{Y}=155,648+0,714 \mathrm{X}$. Dari persamaan tersebut 
dapat diperoleh keterangan jika variabel bebas, yaitu prestasi belajar kewirausahaan mengalami peningkatan satu satuan maka akan menyebabkan kenaikan minat wirausaha sebesar 0,714 .

Berdasarkan hasil penelitian yang dilakukan nilai $t_{\text {hitung }}$ atas prestasi belajar kewirausahaan menunjukkan angka 2,594 sedangkan besarnya $t_{\text {tabel }}$ adalah1,968. Hal ini dapat dilihat bahwa nilai $t_{\text {hitung }}>t_{\text {tabel }}$ yang artinya $\mathrm{H}_{0}$ ditolak.Dalam hal ini besarnya prestasi belajar kewirausahaan mempunyai pengaruh yang positif terhadap minat wirausaha.Dimana nilai koefisien dan $t_{\text {hitung }}$ bernilai positif sehingga besarnya prestasi belajar kewirausahaan berpengaruh positif terhadap minat wirausaha.Dengan demikian, hipotesis nol $\left(\mathrm{H}_{0}\right)$ menyatakan bahwa "tidak terdapat hubungan antara prestasi belajar kewirausahaan dengan minat wirausaha siswa SMK Negeri 3 Singaraja" dinyatakan ditolak.Hal ini berarti hipotesis yang diajukan $\left(\mathrm{H}_{\mathrm{a}}\right)$, yaitu "terdapat hubungan yang positif antara prestasi belajar kewirausahaan dengan minat wirausaha siswa SMK Negeri 3 Singaraja" dinyatakan diterima.

Mengacu dari hasil penelitian ini, dimana diketahui bahwa prestasi belajar kewirausahaan siswa berpengaruh secara signifikan terhadap minat wirausaha walaupun dalam kategori sangat lemah.Hal ini disebabkan karena tidak semua siswa yang mempunyai prestasi belajar tinggi mempunyai minat wirausaha tinggi, demikian juga sebaliknya tidak semua siswa yang prestasi belajarnya rendah mempunyai minat wirausaha rendah. Hal ini dipengaruhi oleh factor-faktor atau variabel lain yang tidak terukur dalam penelitian ini, misalnya kondisi fisik siswa, latar belakang orang tua, lingkungan dan lain-lainnya. Penyebab lainnya adalah kurang efektifnya praktik langsung di lapangan atau magang yang dapat menambahkan minat wirausaha siswa SMK Negeri 3 Singaraja, sehingga kedepannya perlu ada kegiatan magang yang lebih intensif dalam menunjang Proses Belajar Mengajar Kewirausahaan guna menambahkan minat wirausaha siswa SMK Negeri 3 Singaraja.

\section{SIMPULAN DAN SARAN}

\subsection{Simpulan}

Berdasarkan hal-hal yang ditemukan dalam penelitian ini, dapat ditarik beberapa simpulan sebagai berikut:

1. Gambaran umum nilai atau prestasi belajar kewirausahaan siswa SMK Negeri 3 Singaraja termasuk dalam diatas rata-rata atau tergolong tinggi dengan nilai rerata 84,267 dan simpangan baku sebesar 4,794. Dengan melihat hasil tersebut, bisa 
dilihat bahwa nilai mata pelajaran kewirausahaan siswa SMK Negeri 3 Singaraja sudah mencapai ketuntasan belajar.

2. Gambaran umum mengenai minat wirausaha siswa SMK Negeri 3 Singaraja tergolong tinggi dengan rata-rata 215,85 dan simpangan bakunya sebesar 224,75. Sedangkan nilai minimum dari minat ini adalah 111 dan nilai maksimumnya adalah 265.

3. Hasil uji hipotesis menunjukkan bahwa terdapat hubungan yang positif dan signifikan antara prestasi belajar kewirausahaan dengan minat wirausaha siswa SMK Negeri 3 Singaraja dengan persamaan garis regresi $Y=155,648+0,714 X$ dan nilai korelasi hitung sebesar 0,152 .

\subsection{Saran}

Dalam rangka turut menyumbangkan gagasan-gagasan dalam pendidikan, maka peneliti memberikan saran-saran sebagai berikut:

1. Melihat hasil dari penelitian ini bahwa prestasi belajar kewirausahaan berhubungan positif tetapi sangat kecil pengaruhnya terhadap minat wirausaha siswa maka jika boleh disarankan agar materi atau kurikulum yang diajarkan lebih khusus atau menjurus kepada materi atau pelatihan dan penjelasan kewirausahaan yang lebih mendetail. Ini diharapkan bisa mempengaruhi minat wirausaha siswa menjadi bertambah tinggi.

2. Dari penelitian ini didapatkan bahwa hubungan prestasi belajar kewirausahaan dengan minat wirausaha sangat rendah sehingga dapat diartikan ada variabel lain sebagai penentu minat wirausaha yang tidak terukur dalam penelitian ini. Oleh karena itu, perlu adanya penelitian lebih lanjut yang mengkaji variabel-variabel lain yang mempunyai hubungan atau mempengaruhi minat wirausaha siswa.

\section{DAFTAR PUSTAKA}

Alma,Buchari.2006.Kewirausahaan. Bandung: Alfabeta.

Arikunto, S. 2005. Manajemen Penelitian. Jakarta: PT. Rineka Cipta.

Arikunto, S.1992. Prosedur Penelitian Suatu Pendekatan Praktis, Jakarta: PT. Rineka Cipta.

Hadi,S. 2000. Statistik 2. Yogyakarta: Andi Offset.

Nasir, M. 1988. Metodologi Penelitian. Cetakan Ketiga. Jakarta: Ghalia Indonesia. 
Sudjiono, Arias. 2005. Pengantar Statistik Pendidikan. Jakarta: PT. RajaGrafindo Persada.

Sumanto, Wasty.1984.Pendidikan Wiraswasta. Jakarta: Bumi Aksara.

Zimmerer, Thomas W.,Norman Scarborough.1996. Entrepreneurship The New Venture Formation. Prentice-Hall International,Inc. 